\title{
Pertencimento, medos corriqueiros e redes de solidariedade
}

MAURO GULHERME PINHEIRO KOURY

\section{Resumo}

Este ensaio busca entender como os processos de construção da semelhança e da dessemelhança entre os indivíduos e os grupos sociais se formam e se informam. Procura compreender também, as bases da afirmação e as maneiras da superação do medo do outro e as estratégias de solidariedade usadas pelos habitantes de um bairro popular. Analisa os processos aparentemente sentidos como polares pelos cidadãos que os vivenciam, e entendido, neste ensaio como opostos e complementares no estabelecimento de ações e afirmações socialmente dispostas no processo permanente de construção de novos significados de pertencimento.

Palavras-chave: Sociabilidade. Medos corriqueiros. Pertencimento. Redes de solidariedade.

\footnotetext{
* Doutorando em Sociologia pelo PPGS-UFSCar. Professor do Departamento de Ciências Sociais da Universidade Federal da Paraíba (UFPB). Coordenador do GREM - Grupo de Pesquisa em Antropologia e Sociologia das Emoções da UFPB.
} 


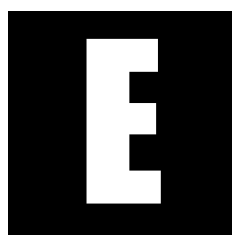

ste ensaio analisa parte do material recolhido durante o trabalho de campo na cidade de João Pessoa, capital do estado da Paraíba, para uma pesquisa sobre a história dos bairros do município ${ }^{1}$. Conta um pouco da história e da atualidade de um dos bairros mais antigos da cidade, o bairro do Varadouro, sob a ótica dos seus moradores, explorando a questão da pertença, das redes de solidariedade em processo de fragmentação e dos medos sociais cotidianos enfrentados pela população residente, quer em relação ao corriqueiro de sua existência, quer em resposta para si e para os outros sobre como a cidade os vê, enquanto bairro apontado como contendo índices altos de violência e pobreza.

É um relato etnográfico onde os entrevistados emprestam a sua voz na definição dos conteúdos temáticos e na constituição de uma problematização do seu bairro e suas relações com ele e com o que a cidade pensa sobre o mesmo. Neste sentido, categorias como a de pertencimento e redes de solidariedade é aqui analisada porque apresentadas nas narrativas dos entrevistados enquanto constituição de mundo presente ou enquanto nostalgia do passado, como chamaria Halbwachs (1995) em seu Les cadres sociaux de la mémoire, ao lado de categorias como a de medos e violência, como interfaces que fundamentam contornos próprios do olhar a si mesmos e seus semelhantes enquanto moradores de um bairro, e a cidade que impõe sobre eles estigmas, impressões, noções e campos de planejamento e controle.

1 Esta pesquisa, por outro lado, faz parte e correspondeu à primeira fase de uma pesquisa maior intitulada: "Medos Corriqueiros: a construção social da semelhança e da dessemelhança entre os habitantes urbanos das cidades brasileiras na contemporaneidade" em desenvolvimento no GREM - Grupo de Pesquisa em Antropologia e Sociologia das Emoções/UFPB, sob coordenação do autor. Além de diversos artigos publicados em revistas nacionais e internacionais, o relatório João Pessoa desta pesquisa foi publicado em 2008 (KOURY, 2008). A segunda fase, que engloba as demais capitais dos estados brasileiros se encontra em fase inicial e os trabalhos de campo terão início em março de 2009. 
Não é um estudo sobre memória, embora baseado em relatos e histórias de vida e na memória dos entrevistados e da cidade sobre o bairro. É antes, um estudo sobre medos, não apenas os grandes medos que compõem a cultura urbana atual brasileira e ocidental, mas, e principalmente, os medos corriqueiros, onde os entrevistados podem contrapor a si próprios com relação aos outros moradores do bairro e com a sociedade pessoense mais geral, e nelas refletir e reviver possibilidades de pertencimento e solidariedade, bem como redefinir os conteúdos impostos a si pela cidade como um todo, como um bairro violento, como um bairro perigoso e recriar os mapas de solidariedade e tensão a que são expostos e que possibilitam a constituição de suas vidas diárias.

Neste sentido, o ensaio parte de uma pequena reconstituição do bairro hoje em dia, enfatizando seu público de moradores e freqüentadores, para compreender como eles explicam o viver no bairro, trazendo à baila a discussão de que pertencer é uma noção vivida pela tensão entre o ontem e o hoje, entre o eu e o outro, entre a solidariedade e o medo e, por fim, entre o situar a si mesmos e, através desse local, ver e hierarquizar os outros semelhantes e ser por eles situados.

\section{Apresentando o bairro}

O bairro do Varadouro, margeado pelo Rio Sanhauá, é um ponto de referência e local de nascimento da capital do estado da Paraíba, Brasil. Ponto onde se concentrava o comércio e a política local até o final do século XIX e primeiras décadas do XX. Faz parte da chamada cidade baixa e dos bairros históricos de João Pessoa.

Hoje é um bairro decadente. O bairro do Varadouro sobrevive sobretudo como ponto de estabelecimentos comerciais para a população de baixa renda e de serviços, com oficinas mecânicas, gráficas, material de construção e de escritório. Abriga uma população pobre em suas ruas 
estreitas e prédios decadentes e mal conservados, junto com um grande mercado informal, constituído de camelôs, bares e locais de prostituição. Acolhe ainda uma população flutuante de homens que vivem de transporte de cargas e transportes alternativos urbanos para os bairros da capital e outras cidades do interior do Estado e Estados vizinhos, sobretudo Rio Grande do Norte e Pernambuco.

Na faixa estreita entre o Rio Sanhauá e a linha férrea estendem-se, ainda, pequenos arruados de casas simples onde sobrevive uma população composta, em sua maioria, de desempregados e subempregados da cidade de João Pessoa, em grande parte oriunda do interior do Estado nos últimos trinta ou quarenta anos. Vivem do comércio informal e da pesca de mariscos e caranguejos no vasto manguezal do rio.

No Varadouro encontra-se também, a estação rodoviária e a estação ferroviária da capital, bem como para lá converge a maior parte das linhas de ônibus da cidade. O terminal dos ônibus de todos os bairros da cidade e de municípios da região metropolitana de João Pessoa fica próximo à rodoviária, facilitando a ida e vinda e a circulação dos habitantes do lugar. Concomitante, há, em suas imediações, um afluxo enorme de pessoas que não moram ou trabalham na região, mas que para lá são atraídas, quer pelo comércio popular que domina o local, quer pelos terminais de ônibus e trens urbanos e intermunicipais e estaduais.

Pelas ruas estreitas do bairro, ao lado de muitos prédios abandonados, destruídos ou em processo de destruição, é possível dar-se conta, ainda, da existência de muitas pousadas e hotéis baratos que sobrevivem no local para abrigar, tanto uma população que vem do interior para a capital, quanto para enlaces amorosos e sexuais com a prostituição local. No bairro do Varadouro, em uma caminhada por suas ruas estreitas, é possível notar também uma quantidade considerável de bares, com apenas uma porta e balcão, ou com um salão onde são dispostas cadeiras e mesas, à noite ampliadas para o espaço das calçadas, e muitas casas de prostituição. Estas últimas, constituídas de uma sala onde funciona o bar e onde as mulheres 
são dispostas à espera de clientes em um corredor com quartos para o atendimento. Muitas das mulheres moram nas próprias casas de prostituição, outras moram, talvez em maior número, em quartos alugados, pela redondeza ou em outros bairros e freqüentam o local profissionalmente.

O mercado local onde se comercializam desde gêneros alimentícios a roupas e artesanato, junto à parada de ônibus que dá acesso aos municípios da grande João Pessoa, concentra uma população móvel e um "chega e parte" enorme de pessoas que trabalham na capital e a ela vêm para estudo ou negócios, ou para simples passeio. Congrega, também, um número considerável de lanchonetes e bares construídos rente à parada de ônibus e de frente para o mercado que atende a esta população, embora também sejam freqüentados por prostitutas e por camelôs, trabalhadores e moradores locais, apesar de que estes últimos sejam poucos.

O bairro do Varadouro, assim, é um bairro central da cidade, de muito movimento ainda nos dias de hoje, apesar de sua evidente decadência. O movimento é garantido pelo bairro que reúne terminais de ônibus estaduais, interestaduais e municipais e a linha férrea da cidade, e ainda, por concentrar um comércio ambulante diversificado pela existência de inúmeras pensões e hotéis que hospedam pessoas vindas do interior do Estado, pela existência de um mercado público variado e pela grande concentração de casas de prostituição baratas da capital ${ }^{2}$.

2 Desde o final da década de noventa do século passado, a área onde se encontra situado o bairro do Varadouro tem sido objeto de discussão para sua revitalização. Hoje faz parte do chamado núcleo histórico da cidade. Esse processo, se levado adianta, planejava recuperar o sítio histórico do bairro e instaurar um pólo turístico e de lazer para a cidade. O que, provavelmente, modificaria o perfil do bairro e dos seus habitantes. Muitos deles deram depoimentos inquietos sobre a possibilidade da sua expulsão gradativa da área. O mesmo acontecendo no comércio ambulante e de prostituição de baixa renda.

Nos anos de 1990 foi inaugurada uma primeira etapa de sua revitalização, concentrando bares, cafés que se tornaram núcleo de lazer para os jovens e intelectuais da cidade e ponto turístico dos mais aclamados. No início do século XXI, contudo, o lugar entrou em franca decadência e as áreas de freqüência dos jovens, intelectuais de classe média e média alta da cidade voltaram a se dirigir para a orla marítima da cidade, principalmente na pequena faixa entre os 
O bairro do Varadouro estende-se também, por uma pequena faixa de terra situada entre as margens do rio Sanhauá e a estrada de ferro. Nessa faixa estreita que transpõe a Rua Porto do Capim, habita uma população carente, em casas simples que compõem uma espécie de arruado, no local onde se localizou a primeira tentativa de um porto na capital, o Porto do Capim.

A Rua Porto do Capim é uma localidade demarcada com facilidade no Varadouro. As casas simples fazem uma espécie de arruado entre a linha férrea, o mangue, o estuário do Sanhauá, abrindo-se para as outras ruas do bairro. Ruas também compostas de uma população de baixa renda, que utilizam casas e prédios em estado grande de deterioração e em péssimo estado de conservação, dividindo o espaço do bairro com um comércio informal, oficinas mecânicas e serviços, bem como, como comentado acima, com bares e casas de prostituição.

Duas linhas ferroviárias, uma delas já desativada há algum tempo e a outra em funcionamento demarcam os limites do arruado. O Porto do Capim, no Varadouro, já fora um centro de entrada e saída importante de mercadorias da cidade de João Pessoa, desde sua origem. Lá era descarregada boa parte das mercadorias que abasteciam a cidade (SILVA, 1997). Segundo um antigo morador da região, aqui chamado de Agamenon, o local "ganhou esse nome porque os soldados do exército iam lá buscar o capim, que servia de ração para os cavalos lá do quartel. lam lá buscar e comunicavam: 'tamos indo lá no Porto do Capim pegar ração'. E foi assim que o nome pegou e o povo ainda hoje usa pra chamar aqui".

Provavelmente, apenas uma estória contada ao pesquisador por um informante. Digna de registro, mesmo sem checar a informação, porém,

bairros de Tambaú e Manaira. Embora ainda se fale da revitalização do centro histórico e se discuta entre os produtores culturais e formadores de opinião da cidade, a discussão não tem sido acompanhada por uma retomada dos projetos de revitalização da área e as discussões são mais críticas e sentimentais ao abandono do lugar pelo poder público, do que, necessariamente, de pressão às políticas públicas voltadas para a cultura e lazer. 
pela perspicácia da construção narrativa e também, porque, entre outros aspectos, este ensaio pretende usar o imaginário dos lugares pesquisados pelos seus habitantes e pelos habitantes do conjunto da cidade.

Dentro do mangue, ainda segundo o informante, encontram-se os restos da base da construção do que viria a ser o moderno porto. Nos anos trinta do século passado, na realidade, foi realizado um vasto projeto, não viabilizado por diversas questões técnicas e políticas, de construção de um moderno porto no local onde tradicionalmente existia um ancoradouro denominado Porto do Capim. A obra foi embargada e, posteriormente deixada de lado, tendo sua verba transferida definitivamente para a modernização do porto marítimo de Cabedelo, cidade que compõe hoje a grande João Pessoa, também nesses anos. Na mentalidade dos moradores que vivem a pequena faixa do arruado do Porto do Capim no bairro do Varadouro, contudo, "o que faltou foi garra política e muito roubo, penalizando toda a região local aqui do bairro de Varadouro e a cidade de João Pessoa em benefício de Cabedelo" (Agamenon).

O que implicou no abandono do bairro como um todo, e

isso aqui que o senhor tá vendo, só gente desempregada, as casas tudo caindo, e a gente se virando como pode. Os ricos se deram bem, se mudaram, foram indo até chegar lá pra praia, os pobres remediados foram se mudando pras áreas que iam se fundando, como Valentina, Geisel, ou mesmo por aqui por perto, como Mandacaru, Padre Zé, o Roger de baixo, e o que não tinha nada como nós, o jeito foi ir ficando, quando não tinha mais morada, levantava, nos fundos de outra casinha, uma frente coberta e ia nós ali ficando. Eu mesmo, veja aí, têm dois puxados, um pra minha filha com dois meninos dela e o outro pro meu menino que se engraçou com uma dona e trouxe ela pra cá pra morar com ele. Tudo apertado mas é o jeito (Dona Martina). 
Nos prédios antigos, já bastante deteriorados, ou mesmo nos já destruídos, mora uma população pobre. Muitos destes imóveis são alugados a baixo custo e outros tantos foram transformados em fileiras de "quartos de aluguel", ou mesmo em pequenos conglomerados de casas de taipa e casebres que tomam o espaço deixado pelos antigos prédios em ruína. Prédios em ruína, casas de taipa, cortiços, arruados, mesclam-se com ruínas de antigas fábricas, depósitos de mercadoria e pequenas oficinas. Na Rua Porto do Capim e adjacências, no bairro do Varadouro, por exemplo, as casas simples encontram-se permeadas por antigos depósitos das mercadorias que chegavam no atracadouro, todos quase sem uso, e pequenas oficinas mecânicas que ainda hoje teimam em existir. As casas e os barracos onde os moradores habitam situam-se, por sua vez, entre a margem do mangue e o final dos prédios antigos.

A população atual é constituída tanto de pessoas que vieram do interior, quanto de pessoas que nasceram e foram criadas na capital. Esta localidade já fora antes mais povoada, quando ainda tinha importância para o comércio geral da cidade. Com o encerro dos armazéns, dos depósitos e das fábricas, houve certa dispersão e, provavelmente, uma interrupção de investimentos na área - uma vez que agora ela já não era interessantemente econômica.

\section{É bom viver no Varadouro}

Apesar dos comentários saudosos e sentimentais dos entrevistados sobre o bairro de antigamente, em comparação com a decadência do bairro hoje, é bom viver no Varadouro. Alegam que o bairro, por ser central facilita a vida de quem nele habita, seja pelo comércio formal e informal que viceja ao seu redor, permitindo proximidade do local de trabalho, como emprego no comércio, nas oficinas, ou mesmo no co- 
mércio ambulante, seja por haver, no bairro, terminais de ônibus locais, facilitando o deslocamento para qualquer parte da cidade, com apenas uma passagem, estaduais, interestaduais e a ferroviária; seja ainda pelo estuário do rio que permite a pesca de caranguejo, além de próximo a áreas de lazer baratas como o Parque Arruda Câmara, a bica, ou o Parque Sólon de Lucena, a lagoa.

A grande questão colocada no bairro pelos moradores é a sua decadência, embora saibam que ainda estão no bairro por causa dela. O movimento de revitalização do Sítio Histórico da cidade, nos anos noventa do século passado, dividiu a opinião de vários informantes. De um lado, encontravam-se aqueles que viam o interesse da cidade pela recomposição do bairro, como um modo de beneficiamento do mesmo e, por extensão, de melhoria das habitações e do viver no bairro. De outro, em sua maior parte, contudo, encontravam-se os que viam o processo de revitalização como mais uma ameaça para os moradores do local como um todo.

A extensão do processo de revitalização terminaria por encarecer o custo das moradias, e o deslocamento para áreas distantes do centro seria inevitável. Esta discussão, contudo, no adentrar do ano 2000, tendeu a abrandar pelo esmorecimento do processo de revitalização que fez muito sucesso nos últimos anos do século passado. Vez ou outra, como agora em 2008, onde o projeto de revitalização da área volta a ser discutido com força, contudo, o receio de serem expulsos do local onde moram é sentido e visto por muitos como uma espécie de fatalidade, que cedo ou tarde acontecerá.

Dona Cruz, moradora do Varadouro, na Rua Riachuelo, fala que mora no bairro desde que chegou a João Pessoa, há uns quarenta anos atrás. Fala do apego ao local e das diferenças entre o tempo passado e o de agora. Indica a saída de vários outros moradores, vizinhos seus em tempos distintos para outros locais da cidade, seja para casas em bairros distantes, no tempo dos conjuntos habitacionais, seja para casas de aluguel em outros bairros e favelas da cidade. 
A vizinhança foi-se embora. Agora tem um ou outro que a gente é íntimo. Falo com todo mundo porque não sou muIher de ficar indiferente, mas não tenho mais aquela coisa de freqüentar a casa, de fazer festa na rua, de conversar nas calçadas. Agora todo qual é em sua casa, quando ainda existe casa, pois quando não é oficina, é casa de puta. $O$ bairro tá deixando de ser aquele que eu conheci, mas ainda é o bairro bom de se morar, perto de tudo, fácil de sair pra qualquer local, um bairro que tem de tudo (Dona Cruz).

O sentimento de perda é evidente no discurso de Dona Cruz. O bairro que "já foi o bairro mais importante da cidade", segundo a informação de Robério, dono de uma banca de venda de redes de dormir perto da rodoviária e morador de uma travessa da Rua Cardoso Vieira,

mas veja só agora, é um desgosto só. Onde eu moro ainda é legal, em vista de outros por aqui ao redor, mas é uma mistura grande. Eu tenho filhos pequenos e já não deixo eles viverem na rua. Primeiro porque é muito movimentado, gente que vem e que vai que você não mais controla, depois as moças de vida fácil e o público que aparece, depois os moradores decentes que quase já não existem. $O$ ano passado mesmo perdi mais um amigo que morava por aqui, na casa que foi da mãe dele. O proprietário do imóvel obrigou ele a sair com o aumento do aluguel. Agora ele tá lá num condomínio do Alto do Mateus, num local horroroso, cheio de bandidos, e mesmo assim perigando a sair porque não tem recursos de ficar por lá muito tempo pelo aluguel e transporte que aumentou. No lugar que ele deixou foi colocado aquela oficina ali, olhe... o que faz com que a gente que ainda insiste em continuar morando aqui, eu acho, já tá habituado e a proximidade com tudo. No meu caso, do local de trabalho mesmo, pois umas quadras à frente e já tô lá armando minha barraca. Mas é uma tristeza só de se ver...

Ao perguntar, contudo, se Varadouro é um bairro perigoso e do que elas sentem medo, a resposta geralmente é seca e clara, "a gente não tem medo de nada", ou "aqui ninguém tem porque ter medo". O que 
parece entrar em contradição com as declarações sobre a decadência do bairro, da expulsão gradativa dos seus moradores, de não poder mais deixar seus filhos brincarem nas calçadas, da convivência com as casas de prostituição no lugar, entre outras. Quando se pergunta sobre medo para os moradores do Varadouro, a palavra medo está associada à violência urbana tal qual discutida pela mídia da cidade, local de roubos, assassinatos, drogados, ou ponto de venda de drogas, e não pela diferenciação do público e escassez dos moradores e vínculos estreitos entre eles, como no passado. A resposta de que "aqui ninguém tem porque ter medo" busca dar ênfase, assim e principalmente, de que apesar de pobre, o bairro do Varadouro "é um lugar muito calmo".

\section{Pertença e sentimento de discriminação}

A ênfase na calma do lugar, na tranqüilidade existente na localidade, em certa parte visa a responder ao imaginário da cidade em seu entorno que qualifica o local como um ambiente perigoso, local de ladrões e um dos pontos de droga da capital ${ }^{3}$.

A mídia local sempre coloca a região como uma região problema. As páginas policiais notabilizam o lugar como um lugar violento e um perigoso reduto de marginais. Desfazer esta imagem é uma preocupação nítida e enfática. O Varadouro, e principalmente o seu núcleo mais pobre na faixa estreita entre a rede ferroviária e o estuário do Sanhauá, carregam uma imagem com a qual, boa parte das pessoas que vivem lá não concorda e rejeita.

\footnotetext{
3 Em uma pesquisa realizada nas páginas policiais dos jornais da cidade, O Norte, Correio da Paraíba e A União, nos anos de 2002 a agosto de 2004, o bairro do Varadouro aparece como um dos bairros com maior índice de notícias sobre questões policiais da cidade, nos assuntos como roubo, delinquência e consumo e venda de drogas.
} 
Não se encontra em discussão a veracidade, ou não, da imagem transmitida pela mídia local e que faz parte dos moradores da cidade de João Pessoa como um todo, sobre o bairro do Varadouro. Esta imagem, contudo, é vista pelos moradores do Varadouro como uma imagem montada pelas pessoas de fora do bairro como forma de denegrir ainda mais a imagem do bairro como um todo, ou pelo desconhecimento do local, ficando o bairro sobre suspeição, por ser pobre e decadente.

A imagem sentida e elaborada pelas pessoas do bairro, pelos seus próprios moradores, no entanto, é uma imagem oposta ou inversa da imagem da mídia. Assim, vêem o bairro como um lugar calmo, tranqüilo e bom para se morar. Mais, para os moradores, Varadouro é o bairro onde a cidade nasceu.

Buscam enfrentar o estigma do perigoso que cerca o imaginário da cidade sobre os locais de moradia "dos pobres. Nós num somos marginais não, nós somos pobres, somos limpinhos e honestos e temente a Deus. As pessoas aqui são boas, se conhecem, são trabalhadoras e lutam para sobreviver no dia a dia" (Dona Euclídia). São respostas que, por serem bastante comuns, dão uma idéia - ou sinalizam - quanto estas pessoas compartilham uma determinada pressão social e moral e do quanto, ao mesmo tempo, isso tem importância para elas e o quanto elas procuram corresponder a essas certas exigências morais e sociais, a fim mesmo de lutar para "sobreviverem no dia a dia".

Seu José Marinho, morador da Rua da Areia, complementa, aqui é um lugar calmo, muito bom para viver. A gente sente falta de melhoria, a gente sente que falta trabalho para muitos, a gente sente que muitos tão indo embora e a gente já não tem a mesma parceria de antigamente com a vizinhança. Mas nós que mora aqui é tudo gente de bem. Num vejo ninguém ruim por aqui, só se for o povo de fora que vem pra'qui fazer maldade e a gente é que leva a culpa. 
Um outro elemento fundamental da discussão sobre medos levantados pelos moradores do Varadouro, quando confrontados com a questão da imagem do bairro pela cidade e revigorada pela mídia local, é a de que, se existe violência no bairro, não é dos seus moradores, mas de gente que vem de fora. São os de fora do bairro que denigrem a imagem do local, não seus moradores.

Os moradores interpretam o bairro, desse jeito, como um local calmo, tranqüilo e bom de se morar, apesar da decadência visível do lugar e do esvaziamento do bairro como moradia por moradores antigos do lugar, e não como um local perigoso, como trata a mídia local. Por outro lado, afirmam que, se existe violência, ela vem de fora do bairro, seja pelo movimento na hora do comércio, com inda e vinda de pessoas de todas as espécies e de todos os cantos de João Pessoa, seja pelos usuários da prostituição local, que tomam os bares e casas de repouso para seus fins, durante toda a noite, seja ainda pela linha do trem, caminhos fronteiriços com outros bairros, como a Ilha do Bispo e Roger e Mandacaru, de onde vêm "os bandidos, de fora, fazer arruaça aqui dentro e manchar a credibilidade do bairro na cidade", como disse Seu Antônio, morador da Rua Porto do Capim, em seu depoimento.

\section{Medos corriqueiros}

A pergunta sobre o sentimento do medo, contudo, ao ser reformulada, mostra um mosaico construído através dos diversos depoimentos dos habitantes do lugar, que retratam uma problemática de diversos temores que fazem parte do cotidiano de sociabilidade no bairro e, no bairro, com relação à cidade. Um dos elementos que configura e dá consistência aos temores dos habitantes do Varadouro diz respeito à visão que a cidade tem do bairro. Os moradores se sentem como que discriminados 
como habitantes da cidade, por morarem no bairro. Daí a necessidade de combater a visão de um bairro problema, com a de um bairro tranqüilo e de colocar a violência que porventura exista no bairro como trazida por pessoas vindas de fora.

Um outro eixo fala sobre os temores da ameaça visível em alguns momentos mais do que em outros, como no momento do processo de revitalização do bairro, por exemplo, da expulsão do local para outros bairros da cidade.

Os residentes no bairro vivem todos sob a ameaça de serem deslocados. Como informa, por exemplo, Dona Vitorina, moradora da Rua Jacinto Cruz,

quem sabe, a qualquer hora a gente pode ser colocado para fora daqui, como já vem ocorrendo nesses quase quarenta anos que moro por aqui. Hoje os vizinhos são escassos, e a gente vive arrodeado de casas fantasmas, tudo caindo, ou de oficinas, lojas e escritórios. Não tem mais aquele clima bom de antigamente, embora seja um local ainda mais do que bom de se morar. Num largo daqui nem morta...

Esses eixos parecem perfazer o contorno das estruturas de significação (GEERTZ, 1978) ambientadas nas tramas cotidianas de sociabilidade onde vão sendo compostas as redes de sentido do bairro. Redes de sentido onde o medo aparece como um elemento do tecido que vai sendo composto nas tramas cotidianas dos moradores em relação a si mesmos e em relação ao bairro como um todo e com a cidade no conjunto. São situações de sociabilidade comuns a todos os moradores do lugar que os fazem partes de uma estrutura geral de significação e memória coletiva do lugar, como um lugar comum, mas também diferentes para cada habitante que vive a problemática de maneira específica e pessoalizada. No geral, contudo, são situações a que estão expostos que, no geral, causam vergonha e constrangimento. 
As situações onde temores afloram nas relações sociais são vistas junto às pessoas que as vivenciam através de uma idéia de fracasso pessoal (KOURY, 2002). A insegurança a que estão expostos como pobres ou como sujeitos de uma situação degradante faz com que os indivíduos nelas expostos, de um lado, tentem negar a sua existência, confrontando com uma visão oposta ou, de outro, enfrentando-a como uma fatalidade (KOURY, 2003). Nas duas possibilidades, o medo ou o sentimento de risco a que se encontram submetidos, ou ainda, a avaliação dos outros a que se sentem envolvidos como moradores do lugar são avaliados através de uma emoção considerada vergonhosa (ELIAS, 1990, 1993).

Essa vergonha parece delimitar as estruturas de significação dos moradores do lugar e os marcam como pessoas que vivem uma situação comum, no interior do bairro e, ao mesmo tempo, diferenciada dos demais bairros e da cidade em geral. Perpassa, porém, entre os moradores do Varadouro, um sentimento comum a outros moradores de outros bairros da cidade, que os fazem pertencentes não só ao bairro, mas a toda a cidade. Esse sentimento diz respeito às mudanças da cidade e às conseqüências dessas mudanças na vida de cada um (KOURY, 2008).

Entre as consequências usuais sentidas pelos moradores do Varadouro que parecem dizer respeito ao conjunto dos moradores da cidade, figura a preocupação com o trabalho, o medo de perdê-lo ou de não encontrar um trabalho. Trabalhar, ter como sustentar a família, dar condições de estudos para os filhos faz parte da preocupação de quase todos os informantes.

"A gente sabe o destino de quem não tem um emprego, né? É pior do que a rua da amargura...", disse Dona Josefa referindo-se a um vizinho que perdeu o emprego e estava de mudança para o interior com toda a família, para a casa de um irmão, pois não conseguia mais manter "o arroz e o feijão na mesa". Ou, como falou Seu Pedro, um trabalhador de oficina 
mecânica desempregado a quase dois anos, já com quase sessenta anos e que não encontra outra colocação:

a vida do desempregado é dura. Depois de um certo tempo os colegas evitam você, os filhos olham você de maneira diferente, e nem a mulher quer fazer mais as obrigações do casamento... a gente, o senhor desculpe pelo palavreado, vira uma merda. E olhe que eu faço bicos aqui e ali. Vendo pipoca na rodoviária, vendo saco nas portas do mercado, carrego compras, lavo carro, faço qualquer coisa pra que tenha a família o que comer. Mas não ter o certo, não ter mais uma profissão como a que eu tinha por muitos e muitos anos, faz a gente perder o respeito da gente com a gente mesmo e de todos em relação a gente.

O emprego e o estar empregado figura assim como um dos elementos norteadores da segurança interior dos indivíduos. A perda do emprego parece significar também o isolamento do sujeito, os colegas não mais aparecem, o indivíduo perde a auto-estima e a confiança dos seus.

Por outro lado, também, reflete nas imagens que fazem do bairro atual em contraponto com o "antigamente" como um local idealizado. Para Dona Eufrásia, moradora da Ladeira da Borborema, "hoje a gente não encontra mais o repouso que tinha com a vizinhança".

Dona Eufrásia se está referindo à rede de solidariedade que ela viveu no passado entre os vizinhos do bairro. Com o crescente esvaziamento dos moradores, em busca de outros locais mais baratos, ou por conta da compra da casa própria adquirida nos sorteios dos conjuntos habitacionais dos finais dos anos setenta e nos anos oitenta do século XX, o bairro está irreconhecível. As casas deixadas pelos antigos moradores se encontram abandonadas ou se transformaram em local de comércio ou serviço.

Com o esvaziamento, as redes de vizinhança foram desfeitas, não mais existe a troca solidária nem o afeto, nem as festas e compartilhamento de antigamente. Agora não tem mais ninguém e quem se encontra, 
encontra-se disperso: "um aqui outro ali, outro acolá, sem vida comum", como complementa Seu Marquinhos, dono de um pequeno estabelecimento comercial e morador nos fundos do estabelecimento, na Rua Amaro Coutinho.

O esvaziamento de moradores no bairro e o crescente número de prédios em ruínas e vazios, junto com o comércio, provocam não apenas o sentimento de quebra dos laços de solidariedade vividos anteriormente pelos moradores, mas também um outro tipo de temor, apontados por grande parte dos moradores entrevistados. Esse temor fala sobre a presença de estranhos que invadem os prédios vizinhos, desocupados, em busca de local de dormida, e "quem sabe, para fazer coisa que num preste", como informou seu Isidro.

Este temor dos estranhos que procuram lugar para dormir e fazer o que não presta, entre as inúmeras edificações desocupadas do bairro, está associado aos "elementos de fora. Sujeitos que procuram o bairro para suas coisas que num sei o que é e nem quero saber, melando o nome do Varadouro na cidade e de todos os seus moradores, gente honesta", segundo o seu Isidro, mas também o temor pessoal de ter sua casa invadida pelos estranhos que vagam entre os prédios em ruínas. O que parece realçar e provocar insegurança.

Dona Eulália, moradora da Rua Porto do Capim, segue em seu depoimento, um caminho análogo ao de seu Isidro e afirma o temor com um fato específico. Informa que já teve seu terreno invadido no fundo de sua casa por estranhos, em várias ocasiões. Fala do terreno invadido por jovens de outro bairro, para jogar futebol e que xingavam e tiravam brincadeiras de má-fé, quando ela ia reclamar. Conta também que já acordou de madrugada com barulho e foi ver, eram dois casais vindos não se sabe de onde que estavam armando uns barracos para morarem no fundo de sua casa. 
Gritei, saí com a vassoura feito maluca, eu e meu filho, e botamos eles pra correr. Mas a gente depois fica insegura, o que vai ocorrer amanhã?, e se eles voltarem, e se houver outra coisa e eu não puder conter? Os vizinhos são poucos e já não temos a mesma aproximação de antes. As casas ali tão abandonadas, acolá são de invasão recente, Mora por perto Seu Pedro, mas ele tá velho e doente, aí fica nós a Deus dará (Dona Eulália).

Seu Pedro, morador próximo de Dona Eulália complementa: "a gente não tem mais sossego. O pessoal vem pela linha (férrea) e invade tudo da gente, rouba os cocos, rouba as bananas, rouba tudo da gente e fica por isso mesmo. É tudo pessoal de fora do bairro..."

Os temores vêm de fora, de pessoas que moram fora do bairro, que atravessam a linha férrea ou que vêm do centro da cidade para cá, na opinião de muitos dos moradores do bairro. Porém subsiste um temor vizibilisado através de um sentimento difuso de saudade do antigamente, isto é, do passado. Este temor difuso diz respeito ao esvaziamento progressivo do bairro: hoje parece não haver mais aquele sentimento de coletividade presente em tempos atrás, não porque mudaram os moradores, mas porque eles foram embora, mudaram-se no decorrer destas últimas três décadas, para outros bairros mais distantes, para outros locais mais acessíveis.

Com a mudança veio o isolamento, a dificuldade de relacionamento. A vivência no bairro e em seu cotidiano de uma forma isolada e não mais compartilhada como outrora. Já quase não há vizinhos para conversar, os prédios vazios se encontram ocupados, ora por comércio, ora por estranhos que chegam à noite e ficam por ali dias e usam o espaço para "fazer coisas" que servem para aumentar a má fama do bairro na cidade.

Esse sentimento de solidão é uma emoção que vai aumentando com o passar dos anos e que atinge a consciência do envelhecimento dos que ficaram. Os filhos cresceram, alguns permanecem no lugar nas puxadas de casa, nas autoconstruções nos terrenos dos pais, mas não permanecem 
por muito tempo. Assim que podem, mudam para outros locais com sua nova família. Ou, como no caso de Dona Cruz, a casa serve de abrigo para as filhas, os netos e para os genros, em um total de onze pessoas, às vezes mais. Quando alguma delas, sem marido, trabalha fora, ou quando o marido de uma delas perde o emprego e não pode mais sustentar uma casa, vem abrigar-se na casa da mãe.

Mas, esses arranjos solidários de Dona Cruz que serve a família maior e especialmente suas filhas, genros e netos, que servem de apoio aos seus, quando em crise financeira ou afetiva, quando se separam dos companheiros, por exemplo, e também é sentido como um arranjo provisório. A unidade, casa, que abriga todos torna-se uma espécie de unidade isolada no bairro.

Os vizinhos se foram, não há mais a troca afetiva, a troca de favores, a segurança do coletivo que havia antes. Hoje Dona Cruz diz que "já não conheço ninguém, quase, por estas bandas". Aponta uma casa e outra onde moram pessoas consideradas próximas, com quem troca umas idéias, mas, no geral, diz que fala com todo mundo, sim, mas não há intimidade.

A velhice chegando, aumenta a sensação da solidão. Não tem mais os parceiros para trocarem confidências, claro que ela se refere aos filhos como ótimos filhos, têm uma proximidade, intimidade e confiança de uma família unida que

agradeço todo dia a Deus por me ter me dado essa felicidade. Mas, o senhor sabe, os filhos são filhos. Tão mais preocupados em receber apoio e certas coisas de uma velha como eu tem necessidade, por mais aberta e segura que seja a relação entre a gente, e não tem que falar. A gente vai ficando cada vez mais só, olha em volta e não tem mais aquelas amigas, a Mariinha, Solange, Fiuzinha e tantos outros amigos e amigas... todos se foram, umas 'pro' interior de volta, acompanhando os filhos que cresceram, outros espalhados por tudo que é bairro aqui da capital. Vez ou outra, a gente se encontra com uma ou outra ex-vizinha e 
amiga. Mas o tempo de cada uma agora é outro e a gente fica assim relembrando o passado e cada uma volta pros seus afazeres e sua lida diária e passa muito tempo de novo sem se ver. $O$ bairro não é mais o mesmo, não. Antigamente era melhor, mas ainda é o bairro em que eu moro e 'num' quero sair daqui. Tem a facilidade de ser próximo a tudo: a gente vai a pé pra muito lugar, a vida fica mais barata e mais fácil de viver... embora, como o senhor vê, menos segura. A gente fica sujeito a uma solidãozinha, a uma vontade daquelas proximidades de outrora, da camaradagem e do aconchego, nas horas difíceis, dos amigos, dos vizinhos, um acobertando e acolhendo o outro necessitado, um vendo a casa do outro e ajudando a proteger, mas é isso aí, é a vida...

\section{Ou, como disse Dona Socorro, moradora da Rua Frei Vital,}

a gente vai ficando velha e vai ficando muito insegura. A gente vê os filhos crescerem, vêr os netos chegarem, e isso é bom, mas vai também ficando mais só. E a gente fica com medo, medo de sentir alguma dor enorme, de morrer e não ter ninguém junto, medo das novidades do lugar, não reconhece mais as coisas de onde a gente mora. Tá tudo quase igual, a não ser esse monte de prédio em ruína, essas casas abandonadas... A gente procura os velhos conhecidos e não tem mais, só um ou outro, e vai ficando só, botando estranheza em tudo; se aparece um novo vizinho a gente estranha, se vêm esses maloqueiros do bairro de lá (apontando para o Roger) a gente fica insegura, com medo de que façam alguma coisa com a gente e a gente não tem a quem recorrer. Mas isso tudo é velhice, são coisas de gente velha que não tem com o que se preocupar mais, mas fora isso, o canto em que eu moro é o meu canto, só saio daqui pro cemitério... 


\section{A violência vem de fora para dentro}

O bairro, porém, é ainda tranqüilo, no dizer dos entrevistados. Tentam assim desfazer a imagem de um bairro violento que a mídia e o imaginário da cidade insistem em manter. A violência vem de fora para dentro, o lugar favorece pelo esvaziamento que outras pessoas utilizem os espaços vazios para cometerem, talvez, atos ilícitos, mas não é o bairro, são as pessoas de fora. A saída de antigos vizinhos, quase camaradas, isola também os moradores, o bairro já não tem aquela convivência de outrora, daí dá um pouco de solidão e insegurança, mas isso também é imputado à velhice. $\mathrm{O}$ medo de envelhecer é que faz, segundo os informantes, cada um se sentir menos protegido, se sentir com mais receio. Como disse Seu Amaro,

quanto mais velho a gente fica, mais medo a gente tem... É coisa de velho, só. Mas se eu sair daqui, tenho certeza, morro mais cedo do que Deus quer, pois aqui tem a minha vida toda, eu posso lembrar, e lá fora, o que me restará, a não ser uma casa, talvez melhor, talvez, contudo, pior, e eu na mingua da minha sentimentalidade... Deus me livre guarde!

Faz setenta anos que Seu Amaro mora "no pé" da Rua da Areia. Mora no mesmo lugar onde sempre morou. Tem muitas lembranças do local, das cachaças que tomou com os colegas, das "muitas" namoradas que teve, do emprego na fábrica Matarazzo, da sua mulher, hoje morta, com quem viveu quarenta anos e que morava "parede e meia, quase colada na minha casa e que gostava de mim desde que eu era uma moleca", de seus pais, dos irmãos, hoje todos pelo mundo, dos filhos e dos netos que "quase não os vejo, só vez ou outra quando aparecem por aqui, e cada vez mais raro agora". Sente falta dos vizinhos que morreram ou se foram ou são quase desconhecidos agora. Vive isolado, vive inseguro, vive com medo. Mas o medo são receios difusos "de gente velha", vive com saudade, também e principalmente. Mas, continua: 
é uma saudade danada de boa de um tempo bom, cheio de dificuldades como é cheia de dificuldades a vida, mas nunca faltou comida... Sempre tive emprego, criei os filhos, vi o bairro se afundar cada vez mais, com a saída dos moradores em busca de um canto melhor ou mais em conta, e eu fui ficando e vendo tudo mudar e continuar sendo o meu canto. Conheço tudo aqui, cada pedra, cada pedaço caído. É o meu canto, daqui só pró Boa Sentença.

Dona Augustina, por sua vez, moradora da Rua Idaleto, falando dos seus medos, relata as mudanças no bairro em que mora há quarenta e tantos anos. Fala do medo de envelhecer, fala dos filhos que tenderão a ir embora, embora dois ainda morem com ela, fala dos estranhos que vêm dos outros bairros pela linha férrea para fazer "o que não presta", conta vários casos ocorridos na sua propriedade, já invadida diversas vezes por motivos vários, fala dos jovens mal-educados de hoje que jogam bola no quintal dela, xingam ela quando reclama, não a respeitam, mas, também, lembra do tempo "de antigamente". Recorda a vizinhança solidária; rememora as árvores bonitas no seu quintal que plantou ou ajudou os seus pais a plantarem; relembra a plantação de subsistência no pequeno terreno atrás de sua casa, feita por sua mãe e, nos fins de semana, ajudada por seu pai, e sente saudade. E esta saudade do passado se transforma em medo da solidão, em insegurança de não ter mais a quem recorrer: quer seja vizinho, os pais, ou, ainda, os companheiros que teve.

Fala do medo que sente, sozinha, quase todo o tempo, pois seus filhos "não param em casa, às vezes chegam apenas para dormir", de ter sua casa invadida, ou de ser roubada. De que o bairro hoje "tem muita gente mal-encarada" e ela, sozinha, fica "encolhidinha no meu canto com receio de ser roubada e até mesmo, Deus me livre, morta". O medo de ladrões, de malfeitores, ela sabe, é fruto das histórias que ouve no rádio "o dia todo", diz que não conhece nenhum caso concreto por perto, a não ser "as mal-criações dos meninos e dessa gente que invade o nosso 
lugar". Associa, assim, o medo à solidão e aos estranhos que "invade o nosso lugar" e, principalmente, ao que o rádio fala do que acontece a todo o momento na cidade e no Varadouro, de modo especial.

No bairro, assim, o temor é direcionado ao estranho, que vem de outros bairros, que habita os prédios vazios, que vagam calados entre uma e outra ruína. São os cheira-colas ou maconheiros, os safados, e tantas outras denominações usadas pelos habitantes do lugar. Há também o medo da polícia, devido à brutalidade com que lidam com as situações para as quais são chamados para resolver: brigas de casais, roubo de frutos das árvores frutíferas dos quintais das casas, como bananeiras, mangueiras, acerolas, para conter um ou outro bêbado, entre outros casos corriqueiros.

Vilar (2001, p. 50) afirma que esse medo da polícia pela população local indica mais "certa falta de sensibilidade (da polícia) que assusta" os moradores. Essa falta de sensibilidade parece intimidar a todos, moradores e estranhos.

Pode-se colocar a falta de trabalho e a falta de perspectiva como situações que causam ansiedade e medo. A idéia de fracasso e debilidade pessoal pesa nas histórias contadas, gerando um desconforto pessoal e coletivo, desde que as narrativas falam sempre de vários casos vistos e vividos que orientam uma ação reflexiva pessoal de intimidação frente ao futuro.

O medo de ser afetado pelo desemprego gera angústia. Quase todos os informantes têm histórias de vizinhos, familiares, quando não de si próprios por períodos difíceis gerados pela falta de trabalho e a perspectiva de um novo engajamento, que sempre custa a chegar, em um novo trabalho, e a falta de esperança para uma melhora na qualidade de vida pessoal. Quem tem um negócio próprio, como Seu Ermelindo, morador da Rua Três de Maio há cerca de 30 anos, tem medo da falência, de não 
vender o suficiente para repor o estoque de seu negócio e manter sua família. Seu Ermelindo fala sobre esse medo que tem

assustado nós o tempo inteiro, pois nós que vive de conta própria sabe que nos últimos anos as coisas têm piorado muito, mas o que fazer senão continuar tentando. Mas o frio na barriga, vez ou outra, quando a gente pensa como agora sobre o amanhã, tem sido quase constante... eu não sei não.

\section{Conclusão}

São situações banais e corriqueiras, assim, que parecem preencher e dar forma e sentido ao cotidiano dos moradores do bairro do Varadouro. Situações estas intercaladas de uma visão sentimental sobre um passado em que se dizia haver um maior número de habitantes, uma melhor qualidade de vida e uma maior solidariedade entre os vizinhos. Onde havia certa cordialidade e afetividade nas relações sociais entre os moradores, uns ajudando os outros em situações diversas: desde a preparação de festas na casa de um ou outro, na comemoração de aniversários de filhos, de casamentos, ou da preparação coletiva de festas na rua, nas festividades de São João e São Pedro, até a solidariedade nas situações dramáticas como perda de emprego, doença ou morte de um outro morador.

A decadência do bairro, o receio de serem expulsos se houver uma reforma no local e, ao mesmo tempo, a angústia trazida pela deterioração completa do lugar dão margem, também, à insegurança e sentimento de exclusão social. Acompanhados por uma defesa do bairro frente ao imaginário da cidade que o retrata como violento, ao mesmo tempo em que se sentem desamparados pela intimidação dos outros, dos que vêm de fora, de outros bairros "para perturbar por aqui".

Do conjunto de receios dos moradores fazem parte as dificuldades trazidas pelo envelhecimento e pela incapacidade de poder sustentar a 
si e a família. Estas reações aparecem associadas ao medo da velhice, do desemprego, do desamparo social, da insegurança pessoal provocada e falta de perspectiva de que a vida vai melhorar para cada morador e para o bairro em geral.

O bairro do Varadouro, enfim, dentro de uma ótica de reflexão sobre o ontem e o hoje, vai refazendo as suas bases compreensivas e estruturas de significação sobre os próprios moradores e, do bairro como um todo. Medos e seus enfrentamentos, vistos em direção ao futuro, como uma ameaça permanente, ou visto em direção ao passado, recheados de sentimentalidade, compõem os cenários de conformação do sentido de pertença ao bairro e sua rede vincular com os demais bairros e da cidade de João Pessoa como um todo.

\section{Belonging, current fears and nets of solidarity}

\section{Abstract}

This essay looks for to understand as the processes of construction of similarity and of dissimilarity between social individuals and groups are formed and are inquired. This paper search to understand, also, the bases of affirmation and ways of overcoming of fear of the other, and the strategies of solidarity used for the inhabitants of a popular quarter. This essay still analyzes the processes seen, apparently, as polar for the citizens that live deeply them, and understood in this work as opposing and complementary in the establishment of action and affirmations socially made in the process of construction of new meanings of belonging. Keywords: Sociability. Current Fears. Belonging. Nets of Solidarity.

\section{Referências}

ELIAS, Norbert. O processo civilizador. 2 vols. Rio de Janeiro: Jorge Zahar, 1990 [1993]. 
GEERTZ, Clifford. A interpretação das culturas. Rio de Janeiro: Zahar, 1978.

HALBWACHS, Maurice. Les cadres sociaux de la mémoire. Paris: Plón, 1995.

KOURY, Mauro Guilherme Pinheiro. Medos Corriqueiros: Em busca de uma aproximação metodológica. Cronos, v. 3, n. 1, p. 94-101, 2002.

. Sociologia da emoção: o Brasil urbano sob a ótica do luto. Petrópolis: Vozes, 2003.

. De que João Pessoa tem medo: uma análise em antropologia das emoções. João Pessoa: Editora Universitária, 2008.

SILVA, Lígia M. Tavares da. Forma urbana e cotidiano na evolução de João Pessoa. Saeculum, n. 3, p. 161-186, 1997.

VILAR, M. da C. Medo na Cidade: uma experiência no Porto do Capim. João Pessoa, Monografia. (Orientador: Mauro Guilherme Pinheiro Koury). João Pessoa, CCS/UFPB, 2001.

Recebido: 02/09/2008

Aceite final: 23/09/2008 